Print ISSN: 2288-4637 / Online ISSN 2288-4645

doi:10.13106/jafeb.2020.vol7.no12.909

\title{
Micro- and Macro-Level Factors Determining Financial Performance of UAE Insurance Companies
}

\author{
Soumya SASIDHARAN ${ }^{1}$, V. K. RANJITH ${ }^{2}$, Sunitha PRABHURAM ${ }^{3}$
}

Received: September 10, 2020 Revised: November 02, 2020 Accepted: November 16, 2020

\begin{abstract}
The research aims to analyze the firm-specific and macroeconomic factors that affect insurance company's financial performance. The research explores the variables that influence the financial performance of the United Arab Emirates (UAE)' insurance companies. The analysis for determining financial performance considers the following variables: the firm's age, retention ratio, capital adequacy, underwriting risk/loss ratio, financial-leverage, reinsurance dependency, and macro-economic factors such as GDP per capita, inflation rate considered as independent factors. The return-on-asset (ROA) is the key measuring indicator; it is regarded as the dependent variable for financial performance measures. The research focuses on secondary information obtained from insurance companies' financial statements. The researcher targeted 18 insurance companies listed on the UAE stock exchanges for study purposes. The research examines the overall factors that influence the financial performance of an insurance company. For analysis of data, software package of social sciences (SPSS version 20) is used. The studies used correlation and multiple linear regression analysis to determine financial performance and their effects. The analysis suggests that there are important and constructive relationships between the size, capital adequacy, and reinsurance dependency, while loss ratio, retention ratio, and financial leverage indicate a major negative relationship. And there's no link between GDP per capita and inflation.
\end{abstract}

Keywords: Financial Performance, Capital Adequacy, Financial Leverage, Insurance Sector, Regression Analysis

JEL Classification Code: F62, G20, G22

\section{Introduction}

In every sphere of life, there are numerous risks. These risks are the basis for the concept of insurance. "Insurance is a contract under which a certain amount known as a premium is charged by the insurer and the insurer guarantees that a large amount will be paid as compensation. (Williams et al., 2002)". Analogous to other companies, insurance firms are earningsdriven. Unless the premiums exceed the actual costs of paying

${ }^{1}$ First Author and Corresponding Author. PhD Scholar, School of Business, Manipal Academy of Higher Education, DIAC, United Arab Emirates [Postal Address: P. O. Box 345050, MAHE, Dubai, United Arab Emirates] Email: soumyasudhi.67@gmail.com

${ }^{2}$ Professor, Manipal Institute of Management, Manipal Academy of Higher Education, Karnataka, India. Email: ranjith.vk@manipal.edu ${ }^{3}$ Associate Professor, School of Business, Manipal Academy of Higher Education, DIAC, United Arab Emirates.

Email: sunitha.prabhuram@manipaldubai.com

(c) Copyright: The Author(s

This is an Open Access article distributed under the terms of the Creative Commons Attribution Non-Commercial License (https://creativecommons.org/licenses/by-nc/4.0/) which permits unrestricted non-commercial use, distribution, and reproduction in any medium, provided the original work is properly cited. claims and other operating expenses, an insurance provider may make a profit. "Insurance firms make profits based on the theory of risk spread and the definition of individual risks" (Levine \& Carson, 2012). According to Masud et al. (2019) the scale of the insurance industry in certain developing countries is limited and unpopular. As a consequence of such situations, the probability of vulnerability remains high. "By transferring the risk away from the individual to the service providers, potential individual's risk preferences will be swayed in a way that will benefit both the customer as well as the serviceprovider" (Rahman, 2018). Insurance firms are major players in the market, who benefit society by enabling individual organizations to share risks that many entities are facing.

Insurance has a history that is as deeply rooted in the history of mankind. The insurance industry is separated into two components: life and general insurance. The risk for life or disability/accident of an individual is covered by life insurance. While general insurance or non-life insurance covers risk to other assets such as property, marine, motor vehicles, health, etc. The insurance industry gained relevance toward the progress of the entire business, which at last prompts the overall achievement of the economy. 
"The signaling theory states that the managers should have more information about the financial performance of the company than others do" (Tabash, 2019). Therefore, it is essential for evaluating the determinant aspects that regulate the financial performance of insurance firms that both internal and external factors should be investigated. However, the financial performance analysis has been extensively studied, but a survey on variables determining the financial performance of insurance establishments in UAE is not much investigated. The lack of empirical research in UAE concerning the insurance firms' financial performance focusing on firm-specific (internal) and macroeconomic aspects (external) motivated the researcher to investigate the financial performance. The economic significance of the insurance sector in UAE and the absence of relevant studies are the main motives for assessing the financial performance of insurance firms and highlighting the variables that determine the financial performance.

\subsection{Overview: UAE Insurance Sector}

UAE insurance industry is a developing market growing to $\$ 18.1$ bn (Dhs66.4bn) by 2021 (Insurance authority, UAE). Additionally, UAE insurance sector's gross written premium (GWP) grew by $8.3 \%$ to reach Dhs $23.7 \mathrm{bn}$ in 2019 compared to aggregate of Dhs21.9bn in 2018. The UAE insurance sector is the most dynamic sector due to its critical position in serving the economy nationwide. The UAE insurance industry comprises 62 organizations of which 35 are countrywide insurance companies and 27 foreign insurance establishments (Insurance Authority, UAE).

\subsection{Evolution of UAE Insurance Sector}

The Emirates Insurance Association (EIA) formed on 27/09/1988 was enlisted according to the Ministerial Decree No. (62). Their members encompass insurance organizations operating in UAE as well as insurance-associated experts. The insurance segment in UAE is administered by the Federal Law of 2007. The Insurance Authority (IA) implements requirements and administers and monitors the coverage organizations and insurance professions. The important objective of IA is to ensure appropriate surroundings for the progress of the insurance zone, which will shield the national economic system and make investments in the countrywide financial savings to maintain the monetary improvement of the UAE. Likewise, it encourages honest and powerful competition by offering first-rate coverage services with tentatively sound rates and adequate coverage inside the UAE insurance market.

\subsection{Objectives of the Research}

- To identify the relationship between firms-specific factors (internal) on financial performance of insurance companies.

- To analyze the relationship between macro factors (external) on financial performance of insurance companies.

- To examine the overall impact of variables that affects the performance of insurance companies.

\section{Literature Review}

The financial performance in the comprehensive term refers to the grade of financial goals that have been accomplished, which is used to evaluate a firm's total financial health. It is the process of determining a company's profitability, growth, and market value in monetary terms. The determinant factors that affect financial performance can be categorized as firmspecific factors and macroeconomic factors. The coming consecutive section of the review examines the concept of the insurance sector and the determinant factors of the financial performance, i.e., both general insurance and life insurance.

Malik (2011) identified the connection between internal variables and ROA of Pakistan insurance firms. According to him, the insurance acts as a significant part in economic steadiness, entrepreneurial activity, trade and commerce, improving savings and quality of life. He recommended that distinct techniques be used to evaluate profitability, but the best option is ROA. For measuring the profitability of Pakistani insurance firms, the researcher considered five variables: age, size, capital volume, leverage, and loss ratio. The research demonstrates that there are no connection between the firm's profitability and its age. ROA is positively influenced by the size and the amount of capital, and is negatively impacted by leverage and loss ratio.

With regards to developing markets, Charumathi (2012) examined the influence of six independent factors, namely, leverage, firm's size, liquidity, underwriting risk, equity capital volume, and premium growth rate regressed to ROA. The examination timeframe incorporates three monetary years, 2008-09, 2009-10 and 2010-11. The study is based on life insurers of India (22 private and one public). The study inferred that size and liquidity have a positive impact, while premium growth rate, leverage, and equity volume have an adverse outcome on fiscal activity. The investigation reveals no evidence about the relationship between profitability and underwriting risk.

Sambasivam and Gashaw Ayelle (2013) stated that profitability is the significant determinant of any institution. The specific factors, which affect profitability, are the company's age, size, capital volume, leverage, liquidity ratio, 
growth, and tangibility. In this, profitability is a dependent factor and others are independent factors. The key indicator to measure profitability is ROA, it is positively related to growth, firm's size, capital volume, but negatively affected by leverage and liquidity. The study shows there is no association between profitability, firm's age, and tangibility of assets. The researcher identified growth, size, leverage, capital volume, and liquidity as the substantial variables of profitability.

Batrinca and Burca (2014) analyzed financial determining elements at the micro and macro-economic for the 2008-2012 period. The study was conducted with 21 companies from 41 insurance firms operating on the Romanian insurance market. To discover the variables influencing the financial performance, 13 variables such as financial leverage, business size, number of years of operations in the Romanian market, gross written premium development, equity, complete marketplace value, diversification, risk underwriting, investment ratio, reinsurance, retained risk ratio, solvency margin and per capita GDP development, which were selected as independent factors. The economic activity of assurance businesses evaluated by ROA is taken as dependent variables. The studies used particular panel data methods and the results show that financial leverage for insurance, the size of a business, GWP, retention ratio, risk underwriting, and solvency margin are determinants of the Romanian assurance market.

Taha (2015) investigated the effect of profitability for the period 1995-1996 to 2013-2014 on two Egyptian insurance establishments listed on the stock exchange. He chose factors like firm's size, leverage, loss ratio, capital adequacy, liquidity, and inflation rates as independent factors, and profitability as a dependent factor. ROA was used to calculate profitability. The outcome reveals no connection with the company's profitability and age. The capital, liquidity, and firm's size are positively associated with profitability. The finding shows profitability is negatively related to the inflation rate, loss, and leverage ratio.

Alomari and Azzam (2017) analyze the impacts on the profitability of 24 listed Jordanian insurance firms from 2008-2014 looking at business size, leverage ratio, market share, and underwriting risk as well as macro-economic factors GDP and inflation. ROA was selected for measuring profitability. This investigation shows that profitability has an adverse effect on liquidity, leverage, and underwriting risk. Company size, market share and GDP affect the profitability of Jordanian insurance firms significantly and positively. This examination revealed that the insurance industry in Jordan has no big effect on inflation and profitability.

Mazvional et al. (2017) carried out a multiple linear regression and factor analysis for identifying the variables affecting the performance of insurance firms. They have chosen ROA as their dependent variable, while expense ratio, inflation rate, retention ratio, claims ratio, company's size, liquidity, equity capital volume, leverage, and growth of the business are independent variables. According to the analysis claims ratio, retention ratio, expense ratio, and size of a firm have an adverse impact on ROA. While leverage, the growth, inflation, equity, and liquidity ratio affect positively performances of insurance organizations in Zimbabwe.

Berhe and Kaur (2017) selected 17 public and private sector insurance firms from 2005-2006 to 2014-2015. ROA was considered as a substitution to profitability. The researcher investigates firm-specific and external variables such as the company's size, leverage, liquidity, loss ratio, capital adequacy ratio, market share, GDP growth, and inflation. The research found that the main determining factors of profitability were variables like size, capital adequacy, liquidity and GDP. However, profitability was not substantially linked to loss ratio, leverage, inflation, and market share.

For Banerjee and Majumdar (2018), the economic crisis of 2007-2008 witnessed a failure for growth rates in UAE insurance sector. The research focuses on the fiscal performance of the insurance segment post-global economic crisis for the period 2009-2013. This study analyzes company's specific variables such as firm's size, growth in GPW, loss ratio, investment ratio, solvency margin, risk retention and market share influence the profitability of insurance businesses evaluated by ROA. The researchers pointed out the consequence of profitability on macroeconomic factors like inflation, per capita GDP, and stock exchange general indices. The study reveals GDP has a positive outcome on the effectiveness of UAE insurance businesses.

Rashid and Kemal (2018) analyzed data from panel regression models to identify the determinants of the profitability of insurers in Pakistan. STATA 12 is used for data analysis. A fixed-effect and random-effect regression models are adopted to properly assess both internal and external factors affecting the company's profitability. Later, the Hausman test is used to check which technique of estimation is best applied in this analysis. Overall profit (ROA), underwriting profit (UP), and investment income (INI) are taken as proxies of profitability.

Deyganto and Alemu (2019) discuss the factors affecting the financial performance of insurance companies operating in Hawassa City Administration, Ethiopia. The researchers selected six general insurance companies out of 17 insurance companies that have audited financial statements for 10 years, from 2008 to 2018. The researcher identified eight explanatory variables and ROA as a dependent variable. The results of this study showed that five factors, such as underwriting, premium growth rate, solvency ratio, GDP 
growth rate, and inflation rate, have a significant impact on the financial performance of Hawassa City Administration insurance companies. Whereas reinsurance dependency, company size and interest rate do not influence financial performance significantly.

Batool and Sahi (2019) analyze US and UK insurance companies during the global financial crisis (2007-2016). The quarterly data of 24 insurance firms from the 2007 are collected. The technique applied was panel data analysis, which embraces fixed-effect model and random-effect model. They have chosen eight independent variables. The internal variables as liquidity, size of firm, asset turnover, leverage and macro variables such as GDP, CPI (Cost per Impression), interest rate and WTI (West Texas Intermediate). The profitability indicators such as ROA and ROE are dependent variables. Company size, liquidity, debt, asset turnover, GDP and WTI have a positive effect in the USA though CPI, while interest rate has a negative and significant effect. Nevertheless for UK insurers, company size, liquidity, CPI GDP, and WTI have a positive impact, but debt, interest rate, and asset turnover have significant negative effect; US insurance revealed to be in contrast with UK. The authors argued that "insurance companies should increase the firm liquidity and decrease the leverage ratio in order to improve the financial performance of insurance companies based in the UK".

\section{Research Hypotheses}

Based on in-depth literature review, the following hypotheses are formulated.

H1: There exists a positive relationship between firm's size and the financial performance of insurance companies.

H2: There exists a positive relationship between capital adequacy ratio and the financial performance of insurance companies.

H3: There exists a negative relationship between retention ratio and the financial performance of insurance companies.

H4: There is exists a negative relationship between loss ratio and the financial performance of insurance companies.

H5: There exists a negative relationship between financial leverage and the financial performance of insurance companies.

H6: There exists a negative relationship between reinsurance dependence and the financial performance of insurance companies.

H7: There exists a positive relationship between GDP per capita and the financial performance of insurance companies.

H8: There exists a negative relationship between inflation and the financial performance of insurance companies.

\section{Research Methodology}

The study attempts to analyze the determinant aspects that affect the financial performance of insurance companies in UAE. This research is dependent on secondary sources of data from financial statements (income statement, balance sheet, etc.) of insurance establishments. The scope of the study is based on the insurance businesses in UAE from the period 2010-2018. For the study, 18 insurance companies in UAE listed on stock exchanges such as Dubai financial market (DFM) and Abu Dhabi securities exchange (ADX) are considered. The financial statements are acquired from Thompson Reuters database. The statistics for macroeconomic factors are retrieved from the World Bank websites and International Monetary Fund. Convenient sampling method is used for selected companies' data available and the number of years the insurance establishment has been operating. For analysis of data, SPSS is used. The literature review supports the idea of both internal and macroeconomic variables such as the size, capital adequacy ratio, retention ratio, loss/risk ratio, financial leverage, reinsurance dependence, growth rate and macroeconomic variables, for instance GDP per capita and inflation rate affect economic performance of organizations.

\subsection{Model specification}

Based on the hypotheses, multiple econometric model regression is employed to assess the impact of both internal and external factors of insurance firm's financial performance.

$$
\begin{aligned}
F P_{i t}= & x_{0}+x_{1} \text { Size }_{i t}+x_{2} \text { Cpa }_{i t}+x_{3} R r_{i t}+x_{4} \text { LossRatio }_{i t} \\
& +x_{5} \text { Lev }_{i t}++x_{6} \text { Reins }_{i t}+x_{7} \text { GDPr }_{t}+x_{8} \text { Infr }_{t}+e_{i t}
\end{aligned}
$$

Where;

$F P_{i t}=$ Financial performance $(\mathrm{ROA}$ of an insurer $\mathrm{i}$ at time period t)

$x_{0}=$ Constant coefficient

$i=$ Signifies a specific insurance company

$t=$ Represent the time period for the study

$x_{1}, x_{2}, x_{3}, x_{4}, x_{5}, x_{6}, x_{7} \ldots x_{8}=$ Coefficient on independent factors

Size $_{i t}=$ Size of insurer $\mathrm{i}$ at time period $\mathrm{t}$

$C p a_{i t}=$ Capital adequacy of insurer $\mathrm{i}$ at time period $\mathrm{t}$

$R r_{i t}=$ Retention ratio of insurer $\mathrm{i}$ at time period $\mathrm{t}$

LossRatio $_{i t}=$ Loss ratio of insurer i at time period $\mathrm{t}$

$L e v_{i t}=$ Financial Leverage ratio of insurer $\mathrm{i}$ at time period $\mathrm{t}$

Reins $_{i t}=$ Reinsurance dependence of insurer $\mathrm{i}$ at time period $\mathrm{t}$ 
$G D P r_{t}=$ GDP per capita at time $\mathrm{t}$

Infr $r_{t}=$ Inflation rate at time period $\mathrm{t}$

$e_{i t}=$ The error term and is independently identically distributed

\subsection{Operational Definitions of Variables}

Return on Assets (ROA): Profit after tax by total assets.

Firm's size: Calculated as natural logarithm of total assets for respective years of insurance firms

Capital adequacy ratio: Equity to total assets.

Retention ratio: Measured by net written premiums to gross written premiums

Loss ratio: Measured as the claims incurred by net premiums earned

Financial Leverage ratio: Measured as debt by equity

Reinsurance dependence: Measured as Gross written premium ceded in reinsurance by total asset

GDP per capita: GDP/Population

Inflation rate: Annual inflation rate of country

\section{Results}

To examine the insurance firm's monetary performance eight independent factors are taken such as the firm size, capital adequacy, retention ratio, loss ratio, financial leverage ratio, GDP per capita and inflation rate. ROA is selected as key indicator to evaluate financial performance and it is taken as a dependent variable. The analytical findings focused on Multiple Regression Model to check the study outcomes for 18 insurance firms in UAE between 2009 and 2018. The factors used in the analysis were chosen considering data availability and depending on applicable literature theory and examination.

\subsection{Descriptive Statistics}

Descriptive statistics are used to define the basic data characteristics within a sample. Descriptive statistics provide details of the sample and the measures taken. They form the basis for effectively quantitative analysis of the data. The descriptive statistics provides mean and standard deviation for selected variables for UAE insurance companies listed in Abu Dhabi stock exchange (ADX) and Dubai financial market (DFM). The mean value of financial performance ROA is .023043 and its standard deviation is .0511435 . Every variables data is shown on Table 1.

\subsection{Correlation Analysis}

Coefficient of correlation reflects the linear relationship among variables. The Pearson correlation coefficient (r) is used. In Table 2, for each correlation, the significance value is calculated which depicts the reliability of the correlation. The correlation analysis on Table 2 indicates that financial performance (ROA) is significant (1 tailed) with firm size, loss ratio, reinsurance dependence, financial leverage ratio, capital adequacy and retention ratio. The analysis shows that firm's size, capital adequacy and reinsurance dependence have significant and positive correlation, while retention ratio, loss ratio, and financial leverage show significant negative correlation. The correlation analysis shows that no substantial relationship exists with GDP per capita and inflation. Correlation matrix advocates the possible existence of issues with multicollinearity that needs to be studied prudently.

Table 1: Descriptive Statistics

\begin{tabular}{|l|c|c|c|c|c|}
\hline & N & Minimum & Maximum & Mean & Std. Deviation \\
\hline GDP per Capita & 162 & -0.1163 & 0.1564 & 0.035641 & 0.068633 \\
\hline Inflation, consumer prices & 162 & 0.66 & 4.07 & 1.844444 & 1.088323 \\
\hline Return on Asset & 162 & -0.2803 & 0.133 & 0.023043 & 0.051144 \\
\hline Firm size & 162 & 1 & 3 & 2.154321 & 0.683169 \\
\hline Capital adequacy ratio & 162 & -0.0035 & 0.7178 & 0.418355 & 0.127853 \\
\hline Risk Retention ratio & 162 & 0.1236 & 0.9877 & 0.518631 & 0.1721 \\
\hline Loss ratio & 162 & 0.078 & 1.9617 & 0.626652 & 0.253803 \\
\hline Leverage ratio & 162 & 0 & 9.84 & 0.17321 & 0.791354 \\
\hline $\begin{array}{l}\text { Re insurance dependency } \\
\text { ratio }\end{array}$ & 162 & 0.0062 & 0.4672 & 0.180886 & 0.083199 \\
\hline Valid N (listwise) & 162 & & & & \\
\hline
\end{tabular}


Table 2: Matrix of correlation

\begin{tabular}{|l|c|c|c|c|c|c|c|c|}
\hline $\begin{array}{l}\text { Pearson } \\
\text { Correlation }\end{array}$ & $\begin{array}{c}\text { Return on } \\
\text { Asset }\end{array}$ & Firm size & $\begin{array}{c}\text { Capital } \\
\text { adequacy } \\
\text { ratio }\end{array}$ & $\begin{array}{c}\text { Risk } \\
\text { Retention } \\
\text { ratio }\end{array}$ & Loss ratio & $\begin{array}{c}\text { Leverage } \\
\text { ratio }\end{array}$ & $\begin{array}{c}\text { Re insurance } \\
\text { dependency } \\
\text { ratio }\end{array}$ & $\begin{array}{c}\text { GDP per } \\
\text { Capita }\end{array}$ \\
\hline Return on Asset & 1 & & & & & & & \\
\hline Firm size & 0.302 & 1 & & & & & & \\
\hline $\begin{array}{l}\text { Capital adequacy } \\
\text { ratio }\end{array}$ & 0.324 & -0.247 & 1 & & & & & \\
\hline $\begin{array}{l}\text { Risk Retention } \\
\text { ratio }\end{array}$ & -0.236 & -0.112 & -0.065 & 1 & & & & \\
\hline Loss ratio & -0.335 & -0.229 & -0.058 & 0.119 & 1 & & & \\
\hline Leverage ratio & -0.324 & -0.086 & -0.295 & 0.012 & 0.303 & 1 & & \\
\hline $\begin{array}{l}\text { Reinsurance } \\
\text { dependency ratio }\end{array}$ & 0.243 & 0.259 & -0.058 & -0.65 & -0.046 & -0.03 & 1 & \\
\hline GDP per Capita & 0.175 & -0.037 & 0.024 & 0.027 & -0.059 & -0.147 & 0.047 & 1 \\
\hline $\begin{array}{l}\text { Inflation, } \\
\text { consumer prices }\end{array}$ & -0.135 & 0.032 & -0.037 & -0.015 & -0.025 & 0.132 & -0.043 & -0.656 \\
\hline
\end{tabular}

\subsection{Hypothesis Testing: Based on Correlation Analysis}

From Table 3, inferences from hypothesis tests have been drawn: -

- We found a positive and significant relationship between firm size and financial performance (ROA). Hence, H1 is accepted.

- The outcome shows a positive significant relationship between capital adequacy and ROA. Thus, H2 is accepted.

- We can see that the retention ratio is related negatively to ROA and is statistically significant. Hence, H3 is accepted.

- The result shows that loss ratio is associated negatively with ROA and is statistically significant. Hence, H4 is accepted.

- The outcome shows that financial leverage ratio is linked negatively with ROA and its relationship is significant. Hence, H5 is accepted.

- The result shows that reinsurance dependence has positive and significant relationship with ROA. Therefore, H6 is rejected.

- We found that the GDP per capita and ROA are not significantly related. Therefore, $\mathrm{H} 7$ is rejected.

- The outcome shows that inflation has a negative and not significant relationship with ROA. Hence, H8 is accepted.

\subsection{Normality of Data}

Before conducting regression analysis, we should check the normality of data. The statement of normality is that the residual average is zero. Hence, the normality of data is evaluated using graphical methods. As a result, the normality test becomes relevant. It can be observed from Figure 1 that the dispersal is a normal curve, suggesting that indications support presumption of normality.

\subsection{Regression Analysis}

In Table 4, $\mathrm{R}$ value is .616 and $\mathrm{R}^{2}$ for regression model is .379 . The model explains $37.9 \%$ of overall variability in financial performance of insurance firms on the basis of these eight variables. The residual $62.1 \%$ of disparity in performance is explained by other factors, which are not included in this model of study. With the variance analysis (ANOVA), it was discovered that the model $\mathrm{F}$ test is equivalent to 11.671 and significant. F-statistics reveals that model validity is significant at 0.000 . The Durbin-Watson test is used in this model of multiple linear regression; the outcomes show that there is no positive correlation between errors in this model. The DurbinWatson test had a value of 1.143 , hence, no indication of autocorrelation.

The validity of the assumptions for the model was assessed by statistical testing. The collinearity problem examined with tolerance and VIF values is exhibits in Table 5. The explanatory variables were checked using variance inflation factors (VIF). The results show that VIF value for all variables is less than 10 and the value of tolerance for all variables is not nearer to zero. It shows that this model is free from problem of multicollinearity.

Regression analysis indicates that:

Regression coefficient firm size .023 reveals when firm's size increases $1 \%$, then ROA increases $2.3 \%$.

Regression coefficient capital adequacy ratio .141 reveals when capital adequacy increases $1 \%$, then ROA increases. $4 \%$.

Regression coefficient loss ratio -.038 reveals when loss ratio increases $1 \%$, then ROA decreases $3.8 \%$. 
Table 3: Correlation among ROA \& Independent variables

\begin{tabular}{|c|c|c|c|}
\hline Hypothesis & Variables & $\begin{array}{l}\text { "Coefficient of } \\
\text { Correlation" (r) }\end{array}$ & P-value \\
\hline 1 & Firm's size & .302 & .000 \\
\hline 2 & $\begin{array}{l}\text { Capital } \\
\text { adequacy } \\
\text { ratio }\end{array}$ & .324 & .000 \\
\hline 3 & $\begin{array}{l}\text { Retention } \\
\text { ratio }\end{array}$ & -.236 & .001 \\
\hline 4 & Loss ratio & -.335 & .000 \\
\hline 5 & $\begin{array}{l}\text { Financial } \\
\text { Leverage } \\
\text { ratio }\end{array}$ & -.324 & .000 \\
\hline 6 & $\begin{array}{l}\text { Reinsurance } \\
\text { dependence }\end{array}$ & .243 & .001 \\
\hline 7 & $\begin{array}{l}\text { GDP per } \\
\text { capita }\end{array}$ & .175 & .013 \\
\hline 8 & Inflation rate & -.135 & .043 \\
\hline
\end{tabular}

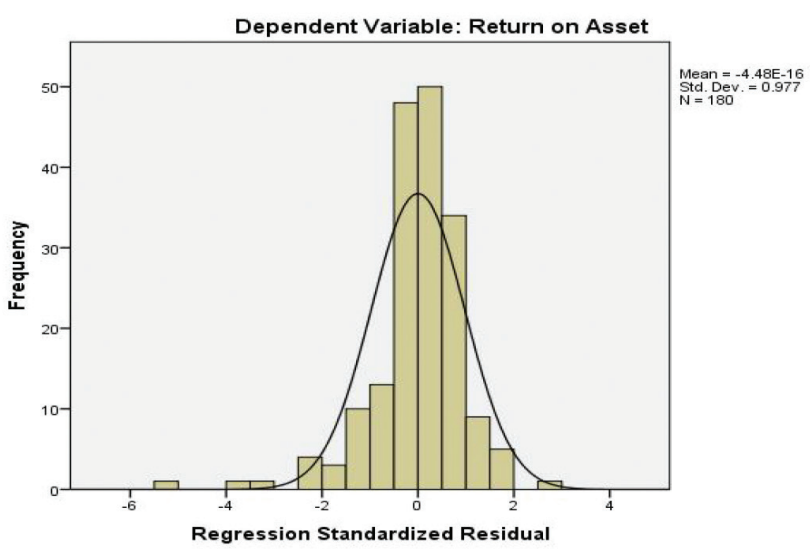

Figure 1: Histogram

Table 4: Model summary

\begin{tabular}{|c|c|c|c|c|c|c|c|c|c|c|}
\hline \multirow[b]{2}{*}{ Model } & \multirow[b]{2}{*}{$\mathbf{R}$} & \multirow[b]{2}{*}{$\begin{array}{c}\mathbf{R} \\
\text { Square }\end{array}$} & \multirow[b]{2}{*}{$\begin{array}{l}\text { Adjusted } \\
\text { R Square }\end{array}$} & \multirow[b]{2}{*}{$\begin{array}{l}\text { Std. Error } \\
\text { of the } \\
\text { Estimate }\end{array}$} & \multicolumn{5}{|c|}{ ANOVA (Change Statistics) } & \multirow[b]{2}{*}{$\begin{array}{l}\text { Durbin- } \\
\text { Watson }\end{array}$} \\
\hline & & & & & $\begin{array}{c}\text { R } \\
\text { Square } \\
\text { Change }\end{array}$ & $\begin{array}{c}\text { F } \\
\text { Change }\end{array}$ & df1 & df2 & $\begin{array}{c}\text { Sig. F } \\
\text { Change }\end{array}$ & \\
\hline 1 & $.616^{a}$ & .379 & .347 & .0413437 & .379 & 11.671 & 8 & 153 & .000 & 1.143 \\
\hline
\end{tabular}

a. Predictors: (Constant), Inflation, consumer prices, Risk Retention ratio, Capital adequacy ratio, Loss ratio, Firm size, Leverage ratio, GDP per Capita, Re insurance dependency ratio

b. Dependent Variable: Return on Asset

Table 5: Coefficients

\begin{tabular}{|c|c|c|c|c|c|c|c|}
\hline \multirow{2}{*}{ Model 1} & \multicolumn{2}{|c|}{$\begin{array}{l}\text { Unstandardized } \\
\text { Coefficients }\end{array}$} & \multirow{2}{*}{$\begin{array}{c}\text { Standardized } \\
\text { Coefficients } \\
\text { Beta }\end{array}$} & \multirow[t]{2}{*}{$\mathbf{t}$} & \multirow{2}{*}{ Sig. } & \multicolumn{2}{|c|}{ Collinearity Statistics } \\
\hline & B & Std. Error & & & & Tolerance & VIF \\
\hline (Constant) & -.058 & .031 & & -1.875 & .063 & & \\
\hline Firm size & .023 & .005 & .304 & 4.292 & .000 & .808 & 1.238 \\
\hline $\begin{array}{l}\text { Capital adequacy } \\
\text { ratio }\end{array}$ & .141 & .028 & .352 & 5.021 & .000 & .824 & 1.214 \\
\hline $\begin{array}{l}\text { Risk Retention } \\
\text { ratio } \\
\end{array}$ & -.026 & .026 & -.089 & -1.036 & .302 & .549 & 1.822 \\
\hline Loss ratio & -.038 & .014 & -.190 & -2.731 & .005 & .837 & 1.194 \\
\hline Leverage ratio & -.007 & .005 & -.109 & -1.531 & .128 & .798 & 1.253 \\
\hline $\begin{array}{l}\text { Re insurance } \\
\text { dependency ratio }\end{array}$ & .066 & .054 & .107 & 1.218 & .225 & .527 & 1.898 \\
\hline GDP per Capita & .091 & .064 & .122 & 1.434 & .154 & .557 & 1.794 \\
\hline $\begin{array}{l}\text { Inflation, } \\
\text { consumer prices }\end{array}$ & -.002 & .004 & -.039 & -.455 & .650 & .562 & 1.779 \\
\hline
\end{tabular}




\section{Discussion}

In line with the results obtained by applying the multiple linear regression model, the study found that size had a positive and statistically significant impact on the financial performance of the insurance sector in UAE. The size of the firms is considered to be significantly associated with financial performances of companies. Some researchers on this field like Sambasivam and Ayelle (2013), Malik (2011), Charumathi (2012) and others show that insurance company size has a positive association with financial performance. Capital adequacy ratio had a positive and statistically significant impact on the financial performance. Capital quantity is a significant measure of economic strength of an insurer and states the capacity of the present capital to promote the further development of assets. Taha (2015), Berhe and Kaur (2017) show capital adequacy to be positively associated with financial performance. The loss ratio is a significant financial performance index expressed as an underwriting risk in the related literature. Alomari and Azzam (2017), Berhe and Kaur (2017) revealed that financial performance is negatively amplified by loss ratio. Contrary to expectations, macroeconomic variables GDP per capita and inflation show an insignificant impact on the financial performance of UAE insurance sector. Batrinca and Burca (2014) revealed that GDP per capita has no impact on the financial performance of the Romanian insurance market. Analogous to this study, Taha (2015), Berhe and Kaur (2017), Alomari and Azzam (2017) also found that inflation has negative and insignificant impact on the financial performance of the insurance sector.

\section{Conclusion}

The importance of insurance varies based on each nation's economic, political, and social conditions. Many studies have been carried out to isolate the characteristics, attitudes and performance determinants of insurance companies in developed countries, few concentrates on developing countries such as Ethiopia, India, UAE, etc. Several researchers have identified various explanatory variables and examined the determinants of an insurance company's financial performance. In the past, several scholars have researched this field, but many topics in the literature are still not addressed. Such gaps are understandable as each country has different cultural, financial, and political systems. Likewise, the insurance industry does not profitably stay the same over the period. The findings revealed that risk retention ratio, financial leverage ratio, loss ratio have negatively significant relationships, while firm size, capital adequacy, and reinsurance dependency have significant and positive relationships. Managers of UAE insurance companies should concentrate on several micro factors to boost their financial performance.

\section{References}

Afza, T., \& Asghar, M. (2012). Performance Determinants of General Insurers in Pakistan, Actual Problems of Economics, 12(138).

Alomari, M. W., \& Azzam, I.M. (2017). Effect of the Micro and Macro Factors on the Performance of the Listed Jordanian Insurance Companies, International Journal of Business and Social Science, 8(2).

Banerjee, R., \& Majumdar, S. (2018). Impact of firm-specific and macroeconomic factors on the financial performance of the UAE insurance sector, Global Business and Economics Review, 20(2), 248-261.

Batool, A., \& Sahi, A. (2019). Determinants of Financial Performance of Insurance Companies of USA and UK during Global Financial Crisis (2007-2016), International Journal of Accounting Research, 7(1), 1-8. https://doi.org/10.35248/2472114X.19.7.194

Batrinca, G., \& Burca, A. (2014). The Determinants of Financial Performance in the Romanian Insurance Market, International Journal of Academic Research in Accounting, Finance and Management Sciences, 4(1), 299-308.

Berhe, T. A., \& Kaur, J. (2017). Determinants of insurance companies' profitability Analysis of insurance sector in Ethiopia, International Journal of Research in Finance and Marketing, 7(4), 124-137.

Burns, A. C., \& Bush, R. F. (2006). Marketing Research (5 ${ }^{\text {th }}$ ed.). Upper Saddle River, NJ: Prentice Hall.

Charumathi, B. (2012). On the Determinants of Profitability of Indian Life Insurers - An Empirical Study. Proceedings of the World Congress on Engineering, Vol. I. WCE 2012, London, UK.

Deyganto, K. O., \& Alemu, A. A. (2019). Factors Affecting Financial Performance of Insurance Companies Operating in Hawassa City Administration, Ethiopia, Universal Journal of Accounting and Finance, 7(1), 1-10. https://doi.org/10.7176/ rjfa/10-5-03

Insurance Authority UAE. (2019). Retrieved November 18,2019, from https://ia.gov.ae.

Levine, C. H., \& Carson, B. M. (2012). Legally Speaking-Loss Prevention and Insurance, Against the Grain, 24(6), 63-65.

Malik, H. (2011). Determinants of Insurance Companies Profitability: An Analysis of Insurance Sector of Pakistan, Academic Research International, 1(3).

Masud, M. M., Rana, S., Mia, A., \& Saifullah, K. (2019). How Productive Are Life Insurance Institutions in Malaysia? A Malmquist Approach. Journal of Asian Finance, Economics and Business, 6(1), 241-248. https://doi.org/10.13106/jafeb. 2019.vol6.no1.241

Mazvional, B. W., Dube, M. B., \& Sakahuhwa, T. (2017). An Analysis of Factors Affecting the Performance of Insurance Companies in Zimbabwe, Journal of Finance and Investment Analysis, 6(1-2). 
Rahman, A. M. (2018). Voluntary Insurance for Ensuring RiskFree On-the-Go Banking Services in Market Competition: A Proposal for Bangladesh. Journal of Asian Finance, Economics and Business, 5(1), 17-27. https://doi.org/10.13106/jafeb. 2018.vol5.no1.17

Rashid, A., \& Kemal, M. N. (2018). Impact of internal (micro) and external (macro) factors on profitability of insurance companies, Journal of Economic Policy Researches, 5(1), 3557.

Tabash, M. I. (2019). An Empirical Investigation on the Relation between Disclosure and Financial Performance of Islamic Banks in the United Arab Emirates. Journal of Asian Finance,
Economics and Business, 6(4), 27-35. https://doi.org/10.13106/ jafeb. 2019.vol6.no4.27

Trochim, M. K. (2020). Research Methods Knowledge Base. RetrievedFebruary 12,2020 from https://socialresearchmethods. net $/ \mathrm{kb} /$ research-data-analysis.

UAE Insurance Industry Report Preliminary. (2019). Retrieved February 15,2020, from http://assets.milliman.com/ektron/ UAE_Insurance_Industry_Report_2019.

Williams, C. A., Smith, M. L., \& Young, P. C. (2002). Risk Management and Insurance $\left(13^{\text {th }} e d.\right)$. Boston, MA: Irwin/ McGraw-Hill. 